3-23-2018

\title{
Boosting the Bugle Boy: The Role of Music in American Patriotism during World War II
}

Brittany L. Roberts

Cedarville University, harpistry21@gmail.com

Follow this and additional works at: https://digitalcommons.cedarville.edu/musicalofferings

Part of the Military History Commons, Musicology Commons, Other American Studies Commons, and the United States History Commons

DigitalCommons@Cedarville provides a publication platform for fully open access journals, which means that all articles are available on the Internet to all users immediately upon publication. However, the opinions and sentiments expressed by the authors of articles published in our journals do not necessarily indicate the endorsement or reflect the views of DigitalCommons@Cedarville, the Centennial Library, or Cedarville University and its employees. The authors are solely responsible for the content of their work. Please address questions to dc@cedarville.edu.

\section{Recommended Citation}

Roberts, Brittany L. (2018) "Boosting the Bugle Boy: The Role of Music in American Patriotism during World War II," Musical Offerings: Vol. 9 : No. 1 , Article 2.

DOI: $10.15385 /$ jmo.2018.9.1.2

Available at: https://digitalcommons.cedarville.edu/musicalofferings/vol9/iss1/2 


\title{
Boosting the Bugle Boy: The Role of Music in American Patriotism during World War II
}

\author{
Document Type \\ Article
}

\begin{abstract}
When the Japanese attacked Pearl Harbor on the morning of December 7, 1941, they little realized what a formidable foe they had aroused. An enraged America immediately declared war on Japan. As a result, Germany declared war on America. Now facing enemies on both fronts, America mobilized her troops for action and prepared weapons of mass destruction. The unity experienced by the American people during this time had never been and would never be matched. Both soldiers and civilians launched themselves into the war effort. This great national endeavor called for anthems of reflection and encouragement. While they continued to sing national favorites such as "The Star-Spangled Banner" and "America the Beautiful," contemporary musicians wrote pieces that directly pertained to the country's present trials and triumphs. New works remembering Pearl Harbor, praising the soldiers and comforting the sweethearts saturated the airwaves and were featured in performance venues. Music gave a tangibility and expression to the deeply felt emotional turmoil of the American people. They identified with and drew comfort from the subject matters it explored. Musicians such as Artie Shaw, Glenn Miller and the Andrews Sisters took tours entertaining troops at home and abroad, giving them courage and strength for the daunting fight they faced. When victory was finally achieved for the Allies on September 2, 1945, the people again turned to music as an outlet for their jubilant celebrations. Thus, music played a significant part in boosting American patriotism and troop support throughout the entirety of World War II.
\end{abstract}

\section{Keywords}

World War II, Patriotism, American Music, Music History, Military Music

\section{Creative Commons License}

\section{(c) $($ EY $(\Theta)$}

This work is licensed under a Creative Commons Attribution-Noncommercial-No Derivative Works 4.0 License. 


\title{
Boosting the Bugle Boy: The Role of Music in American Patriotism during World War II
}

\author{
Brittany Roberts \\ Cedarville University
}

667 esterday, December 7, 1941-a date which will live in infamy - the United States of America was suddenly and deliberately attacked by naval and air forces of the Empire of Japan." ${ }^{1}$ Such was the sobering introduction to President Franklin Delano Roosevelt's Declaration of War, announcing America's entry into World War II. While many European countries had struggled against one another since the thirties, America had remained neutral. She feared global involvement after her recent participation in the Great War, the war that was supposed to end all wars. From the time of World War II's beginning across the sea, more than seventy percent of Americans supported neutrality. However, when the violence reached her own shores on December 7, 1941, her course of action was set. The devastation of the Hawaiian naval base jarred the sleeping giant awake (Figure 1). She dusted off the drums of war and her angry citizens united with a single resolve. They could stay out of the conflict no longer. The time had come to fight.

Clancy Strock, contributing editor of Reminisce magazine, wrote the following in the prologue to a book called 'We Pulled Together...and Won!':

In an instant, the entire nation dropped its differences.

Republican or Democrat, Easterner or Westerner, man or woman, Jew, Catholic, or Protestant, rich or poor, a city mouse or a country mouse-we were in it together

\footnotetext{
${ }^{1}$ Franklin D. Roosevelt, "Day of Infamy” Speech, Dec. 8, 1941, National Archives Catalog 595426, http://catalog.archives.gov/id/595426.
}

Musical Offerings 9, no. 1 (2018): 15-30 ISSN 2330-8206 (print); ISSN 2167-3799 (online)

(C) 2018, Brittany Roberts, licensed under CC BY-NC-ND (http://creativecommons.org/licenses/by-nc-nd/4.0/) 
because we had been attacked! World War II was our war, uniting us as a nation like nothing before or since. ${ }^{2}$

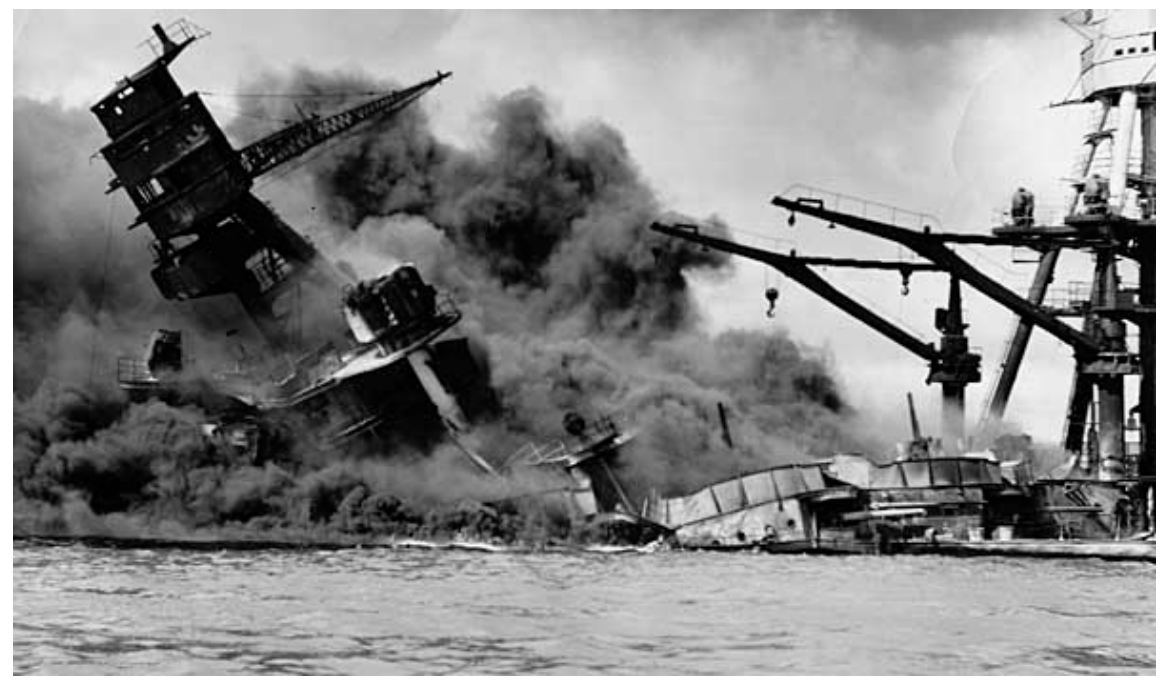

Figure 1: The burning and damaged ships at Pearl Harbor. ${ }^{3}$

Seething with anger, America chose to retaliate by declaring war on Japan. Because of this, Germany's chancellor Adolf Hitler announced his declaration of war against the United States as well. Now facing daunting opposition from both the East and the West, the United States mobilized her troops and joined the Allied forces. The nightmare that was World War II had officially begun for the United States of America.

The crucial decision of the United States to join the war required great support and encouragement from within American borders. This dire need was fulfilled in large proportion by music. From her earliest years, the music of America had fostered national identity and patriotism. Its impact had been especially evident during the Civil War and the Great War, which had produced well-loved classics such as "Dixie's Land," "When Johnny Comes Marching Home," "Pack Up Your Troubles in Your Old Kit Bag,” and "Over There.” The music birthed in this new, dangerous American endeavor, which would come to be known as World

\footnotetext{
${ }^{2}$ Deb Mulvey, ed., 'We Pulled Together...and Won!', (Greendale, WI: Reminisce Books, 1993), 7.

${ }^{3}$ Department of the Navy, Photograph of Burning and Damaged Ships at Pearl Harbor, Dec. 07, 1941, National Archives Catalog 12008992, http://catalog.archives.gov/id/12008992.
} 
War II, boosted patriotism and troop support in a way unmatched before or since.

The music industry pulled together to encourage Americans at home and abroad, using mediums such as radio hits and live concerts to celebrate their efforts of preserving the freedom they all held dear. The music of America during World War II articulated the deep, patriotic unity of her citizens and praised both the tenacity of the boys abroad and the support from those at home. Inspired by these new anthems, American citizens joined forces to achieve a single objective: winning the war.

One of the earliest examples of World War II patriotic song was a piece entitled "We Did It Before (And We Can Do It Again)" by Cliff Friend and Charlie Tobias. The two men, accomplished songwriters working in New York, were compelled to write it as a response to the Pearl Harbor attack, and the work was recorded that month by artists including big band singer/songwriter Dick Robertson and singer/television producer Barry Wood. The song heartened the nation that was reeling in shock. It reflected the tenacity of the American people, and many citizens were highly encouraged by it. Selected excerpts read as follows:

December seventh, nineteen hundred and forty-one

Our land of freedom was defied

December eight, nineteen hundred and forty-one

Uncle Sam replied

We did it before and we can do it again

Millions of voices are ringing

Singing as we march along

We did it before and we can do it again

And we will do it again

This country never has lost a war

From days of William Penn

We did it before, we'll do it again. ${ }^{4}$

This work was one of the first in an abundance of wartime songs that would follow. The atrocity of Pearl Harbor, and the wartime events that followed, filled the American people with a sense of national pride as

${ }^{4}$ Cliff Friend and Charlie Tobias, "We Did It Before (And We Can Do It Again),” Barry Wood and The Wood-Nymphs, Victor Records 27783-A, 1941, http://www.historyonthenet.com/authentichistory/1939-1945/3music/04-PH-Reaction/19411200_We_Did_It_Before-Barry_Wood.html. 
well as with a firm resolve to fight their enemies on both the European and Pacific fronts. New music rushed over the radio waves. Musicians premiered patriotic works in public concerts and wartime gatherings all over the country.

A military favorite of the time was "Comin' In on a Wing and a Prayer," written by Harold Adamson and Jimmy McHugh. The work tells the story of a flight crew who courageously limped back to the base in their plane after a skirmish. Though suspended between earth and sky in a crippled plane, the airmen successfully guided their wounded warbird all the way back to the airstrip. The American grit and determination that were celebrated in this work inspired the Americans at home and abroad to keep fighting, no matter the odds. This was one of the most popular songs of 1943.

One of our planes was missing

Two hours overdue

Yes, one of our planes was missing

With all its gallant crew

The radio sets were humming

They waited for the word

Then a noise broke through the humming

And this is what they heard

Comin' in on a wing and a prayer

Comin' in on a wing and a prayer

Though there's one motor gone

We can still carry on

Comin' in on a wing and a prayer

What a show, what a fight

Yes, we really hit our target for tonight

How we sing as we limp through the air

Look below, there's a field over there

With our full crew aboard and our trust in the Lord

Comin' in on a wing and a prayer. ${ }^{5}$

\footnotetext{
${ }^{5}$ Harold Adamson and Jimmy McHugh, "Comin' In on a Wing and a Prayer," The Four Vagabonds, Bluebird Records 30-0815-A, 1943, http://www.historyonthenet.com/authentichistory/1939-1945/3-music/06Services/19430000c_Comin_In_On_A_Wing_And_A_PrayerThe_Four_Vagabonds.html.
} 
Another famous wartime ballad came out of the Pearl Harbor attack. Navy Chaplain Howell Forgy stayed with the sailors as they sent up a counterattack to the swarming Japanese Zeros. Reverend Forgy is said to have picked up a machine gun alongside the soldiers, saying, "Praise the Lord and pass the ammunition!" ${ }^{\prime}$ The story became legendary (with a few embellishments and exaggerations thrown in) and was developed into a song by Frank Loesser. It was made popular in 1942 by Kay Kyser and his band. The refrain finishes as follows: "Praise the Lord and pass the ammunition, and we'll all stay free!"”

Along with the favorite American songs that frequented the airwaves, famous musicians visited military bases in America and overseas to entertain the soldiers with song and dance. One such figure was the "King of Swing," Glenn Miller (Figure 2). At age thirty-eight, Miller was deemed too old to be drafted when World War II began. However, he found a way to serve when he took command of an Army band in 1942. He served first in the Army before being moved to the Air Corps a short time later. Having already led a big band jazz group for several years with much success, he was duly equipped for his new job. He and his band played at formal events, service clubs, and recreational halls. ${ }^{8}$

\footnotetext{
${ }^{6}$ Nikola Budanovic, "Praise the Lord and Pass the Ammunition: The Legendary Army Chaplain of Pearl Harbor," War History Online, accessed Jan. 23, 2018, http://www.warhistoryonline.com/world-war-ii/praise-the-lordand-pass-the-ammunition-bc.html.

${ }^{7}$ Frank Loesser, "Praise the Lord and Pass the Ammunition," Kay Kyser and His Orchestra, Columbia Records 36640, 1942, http://www.historyonthenet.com/authentichistory/1939-1945/3-music/09Names-Places/19420731_Praise_The Lord_and_Pass_The_AmmunitionKay_Kyser.html.

8 "Biography," Official Website of Glenn Miller, CMG Worldwide, accessed Jan. 23, 2018, http://www.glennmiller.com/biography/.
} 


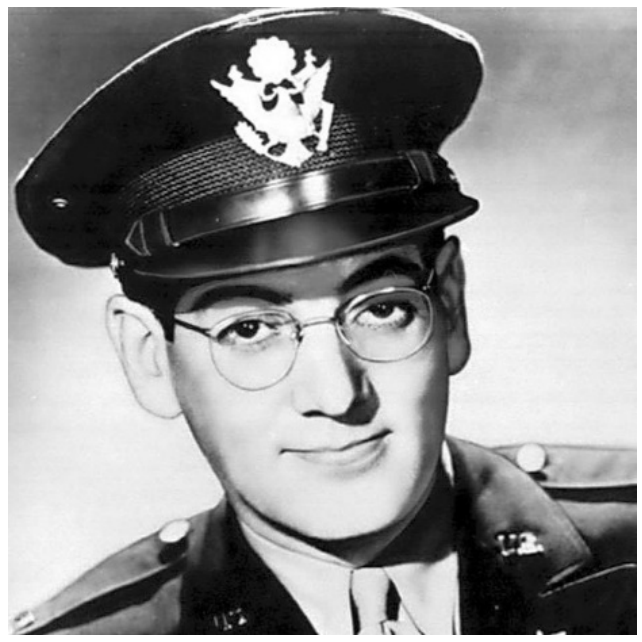

Figure 2: Glenn Miller in uniform. ${ }^{9}$

Miller used influences from his jazz background to rearrange the old military standards. At first, he experienced objections from some of his superiors, who maintained that the old works from World War I were just fine and needed no embellishment. To this, Miller is said to have responded, "Tell me, Major, are you still flying the same planes you flew in the last war too?" ${ }^{10}$ Wherever they performed, Miller and his ensemble were much loved and appreciated by the American forces. He travelled as close to combat as he could, bringing the music of home to grateful soldiers who did not know if they would ever see their beloved land again.

About a concert Glenn Miller and his Air Force Band held at a base in England in late 1944, airman Dick Keller wrote:

Most of the B-17s were moved out of the largest hangar, and a makeshift stage was set up. That hangar was jammed the night of the show. Hundreds of officers and enlisted men and women occupied every available space. The famous Glenn Miller sound and the

\footnotetext{
${ }^{9}$ Brian Arsenault, "Brian Arsenault Takes On: Glenn Miller and His Orchestra,” The International Review of Music, Oct. 02, 2014, http://irom.wordpress.com/2014/10/02/brian-arsenault-takes-on-the-glennmiller-band/.

${ }^{10}$ Ibid.
} 
unforgettable renditions of Johnny Desmond and the Crew Chiefs filled the cold night air. Those classic arrangements propelled us above the homesickness and frustration of wartime, and for a few brief hours, lifted our spirits as nothing else could! ${ }^{11}$

The concert attendees had no way of knowing that that very night was destined to be Miller's final performance. A few days later, on December 15, 1944, his plane disappeared while flying across the English Channel. The unfortunate aircraft and its passengers were never seen again. ${ }^{12}$ Though the man himself was gone, Miller's band continued to perform, and his reputation survived far beyond his lifespan.

Another well-known big band leader and musician was Artie Shaw. Born Arthur Jacob Arshawsky into a Jewish family in New York, he exhibited a natural aptitude for music from his youth. He began by playing saxophone at age thirteen. At age sixteen, he picked up clarinet when he began to travel with a band. He enjoyed the life of a session musician in the 1930s, then he became involved in the big band genre. During World War II, he enlisted in the Navy, entertaining troops with his band in the Pacific, just as Glenn Miller did in Europe.

Soldiers remembered Artie Shaw's concerts for years afterwards, as is evidenced in the story of a group of naval sailors aboard the USS Pringle, who fondly remembered the performance of the "King of Clarinet" and his thirty-two-piece big band on their ship. Far out in the Pacific Ocean, in time with the rhythm of the waves, Artie and his band played their hit entitled "Nightmare," along with other wartime favorites. For the homesick, war-weary sailors, it almost seemed as though time had frozen, the war had ceased, and nothing existed but the music and thoughts of home. They were destined to remember Artie's concert with fondness until the day they died. As sailor Andrew Balog remarked, "We may have had a 'Nightmare' in the Pacific, but it was a pleasant one!"13

Another group which paid homage to American soldiers during the war was that of the Andrews Sisters (Figure 3). Patty, the youngest, was an energetic blonde who sang lead. Maxene, a kind brunette, was the next oldest. She and LaVerne, the red-haired eldest sister, sang the harmony

\footnotetext{
${ }^{11}$ Mulvey, 'We Pulled Together... and Won!', 137.

12 “Biography,” Official Website of Glenn Miller, http://www.glennmiller.com/biography/.

${ }^{13}$ Mulvey, 'We Pulled Together... and Won!', 133.
} 
parts. The tightness of harmony they perfected was superb, and it delighted audiences for many years. After 1938, when they sold 350,000 copies of their first hit album "Bei Mir," they became celebrities. The 1940 s found them in very high demand, making $\$ 20,000$ in concerts per week. ${ }^{14}$

The Andrews Sisters did not rest on their laurels and lead a soft life of show business when the war hit, however. The girls considered it their patriotic duty to give back to those in combat, and they contributed what they could with no hesitation. The women gave their free time to perform for enlisted and wounded men. They also readily signed thousands of autographs for the enthusiastic soldiers. Their singing and dancing delighted the GIs. In June 1945, the sisters took a United Service Organizations (USO) tour for eight weeks and presented shows abroad to thousands of servicemen. As Patty Andrews reminisced, "We were such a part of everybody's life in the Second World War. We represented something overseas and at home-a sort of security."15

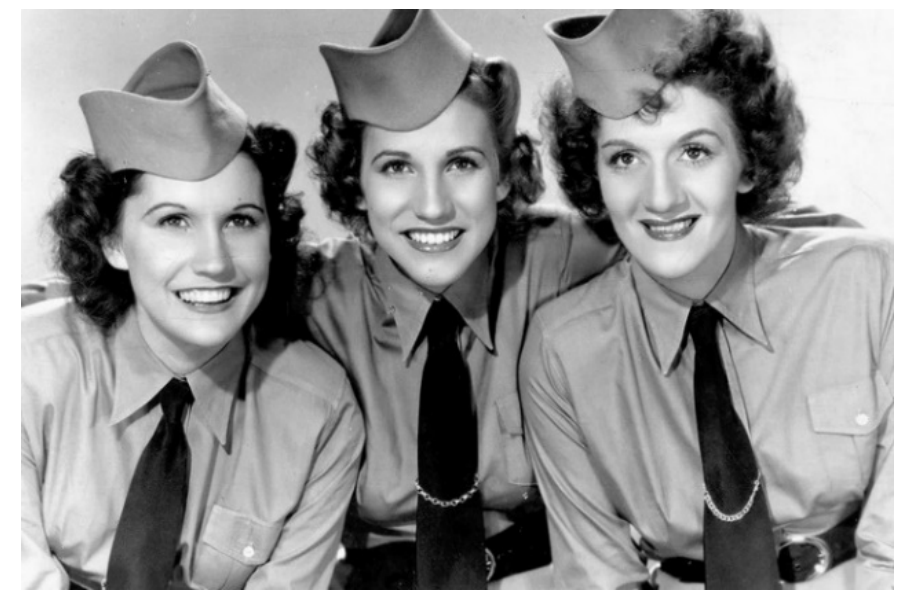

Figure 3: The Andrews Sisters (from left to right): Maxene, Patty, and LaVerne. ${ }^{16}$

\footnotetext{
14 "Biography," Official Website of the Andrews Sisters, CMG Worldwide, accessed Apr. 06, 2017, http://www.cmgww.com/music/andrews/.

15 “Quotes,” Official Website of the Andrews Sisters, accessed Dec. 13, 2017, http://www.cmgww.com/music/andrews/about/quotes/.

16 "Patty Andrews of Andrews Sisters Rallied Troops," Military.com, Associated Press, Feb. 01, 2013, accessed Apr. 06, 2017, http://www.military.com/off-duty/music/2013/02/01/patty-andrews-ofandrews-sisters-rallied-troops.html.
} 
One of the Andrews Sisters' most famous wartime hits was entitled "Boogie Woogie Bugle Boy.” The first two stanzas read as follows:

He was a famous trumpet man from out Chicago way

He had a boogie style that no one else could play

He was the top man at his craft

But then his number came up

And he was gone with the draft

He's in the army now, a-blowin' reveille

He's the boogie woogie bugle boy of Company B

They made him blow a bugle for his Uncle Sam

It really brought him down because he couldn't jam

The captain seemed to understand

Because the next day the cap'

Went out and drafted a band

And now the company jumps when he plays reveille

He's the boogie woogie bugle boy of Company B. ${ }^{17}$

The musical contributions of the Andrews Sisters, Glenn Miller, Artie Shaw, and many others served to boost the morale of the American soldiers and their loved ones. However, while a great deal of music was written to honor the bravery of the Americans overseas, composers and lyricists did not fail to recognize the valiant efforts of the American civilians at home who were supporting the fight from behind. The American people wholeheartedly supported the troops that were being sent across the sea to engage the enemy and protect their beloved homeland, and just about everyone was eager to aid the war effort. Their numerous endeavors to do this included raising funds, donating metal for weaponry, shouldering the work that the soldiers had left behind, and providing necessities for medical relief.

Close to six million American women stepped up to support the war. They joined military aid organizations such as the Women's Air Corps (WAC) and the Red Cross. On the home front, they stepped up to fill the jobs of their husbands, fathers, brothers, and sweethearts. Crowds of women worked diligently in manufacturing facilities to build war materials such as tanks, aircraft, and ammunition for use across the sea.

${ }^{17}$ Don Raye and Hughie Prince, "Boogie Woogie Bugle Boy,” Andrews Sisters with Vic Schoen and His Orchestra, Decca Records 3598-A, 1941, http://www.historyonthenet.com/authentichistory/1939-1945/3-music/03Defense/19410112_Boogie_Woogie_Bugle_Boy-Andrews_Sisters.html. 
To celebrate these women and to showcase the service that they were giving to their country, Redd Evans and John Jacob Loeb composed "Rosie the Riveter" in 1942. A portion of this work reads as follows:

All the day long whether rain or shine

She's a part of the assembly line

She's making history

Working for victory

Rosie the Riveter

Keeps a sharp lookout for sabotage

Sitting up there on the fuselage

That little frail can do

More than a male can do

Rosie the Riveter. ${ }^{18}$

American music educators were keenly aware of the need for quality music to boost morale at home and abroad. They took great care to develop and execute concerts for the benefit of the public. Even the young ones were encouraged to participate in the war effort, and they lent their robust little voices to the American chorus of patriotism. A 1941 article entitled “American Unity through Music” expounded on this concept:

Music is a vital factor in building a state of mind and heart which is essential to American spirit and morale, to worthy pride in things which are American, and to the confidence and assurance necessary to full appreciation, protection, and maintenance of the American Way of Life. To this end, upwards of 45,000 school and college music teachers are intensifying their organized programs of musical activities, not only in the schools and colleges, but in every sphere of our social structure. ${ }^{19}$

The article went on to speak of the need for various music groups to participate in patriotic events as an encouragement to national unity.

\footnotetext{
${ }^{18}$ Redd Evans and John Jacob Loeb, "Rosie the Riveter," The Four Vagabonds. Bluebird Records 30-0810-A, 1943, http://www.historyonthenet.com/authentichistory/1939-1945/3-music/10Pitching_In/19430200_Rosie_the_Riveter-The_Four_Vagabonds.html. ${ }^{19}$ Committee on American Unity through Music, "American Unity through Music,” Music Educators Journal 27, no. 5 (1941): 10, doi:10.2307/3385961.
} 
Perhaps the greatest evidence of the effect that patriotic music had on American citizens comes from the mouths of the citizens themselves. These individuals lived through a crucial time, and though many of them are no longer living today, those who are can speak to the personal impact that music had upon them as they watched the daily unfolding of the horrors of World War II. In 1993, the editors of Reminisce magazine compiled the personal accounts of veterans and civilians, detailing their life experiences during World War II. Many of those who contributed to this accumulation have war memories in which music plays an intrinsic part. Marilyn Russell of Belleair Bluffs, Florida gave one such recollection. One night, she went to the movie theater with her husband. The operators stopped the movie, brought up the houselights, and announced: "The Japanese have bombed Pearl Harbor. Some of our ships have been damaged. The attack came early this morning." Everyone fell dumb with shock, then moans of grief erupted. The operators of the movie theater put the American flag on the movie screen, and "The StarSpangled Banner" was played. The theater-goers managed to sing along, though their eyes were wet with tears. As everyone sang, Mrs. Russell thought about the inevitability of her husband's draft. The full calamity of the attack pushed upon her at a sobering pace. She knew that no one in that theater would ever forget that moment. ${ }^{20}$ Like Mrs. Russell, all of America felt the shock waves of the Pearl Harbor disaster and sought comfort in the age-old anthems of the country. The musical strains rippled through the wounded hearts of a hurting nation, giving them strength and courage for the trial ahead.

The music that impacted American understanding and morale during the war was not limited to national pieces and big band numbers. The country and folk music genres were quick to contribute their own works to fill the patriotic need of the country. They reached an audience generally uninfluenced by other genres. Typically, residents in rural America experienced a level of detachment from the pulse of war news. Their knowledge of the conflict arrived through such mediums as the newspaper, oral transmission, and the radio. Radio programs such as the "Grand Ole Opry," the "National Barn Dance," and "Wheeling Jamboree" reached this American subculture in a way that big band music could not do. Called "hillbilly music" by its fans, the country/bluegrass genre exploded with patriotic numbers remembering sweethearts and encouraging nationalism. Its beloved accompaniment included fiddles, banjos, mandolins, and guitars, rousing hearts to

${ }^{20}$ Mulvey, 'We Pulled Together... and Won!', 17. 
recognize the heroism and heartbreak that emerged from the terrors of war. $^{21}$

While Glenn Miller, Artie Shaw, and the Andrews Sisters travelled abroad to uplift the troops, musicians and entertainers with names not quite as famous provided the same service for the battered soldiers longing for a bit of home. Eileen O'Leary Stein, a Red Cross volunteer who served near the front in Europe, reminisced about her experiences with traveling entertainment:

Serving with the American Red Cross in Europe, I helped operate a mobile entertainment truck called a "Cinemobile." [Figure 5.] It had a piano, movie projector and screens, loudspeakers, and built-in bunks. A stage folded down from one side of the truck, allowing us to do live shows. My partner Effie and I often drove through pouring rain and darkness to entertain isolated GI units in France, Belgium, and Germany. We'd sit on our helmets in the mud with a tarp over the projector while the movies ran. Later, we'd drive in complete blackout to headquarters. One cold November day in Metz, France, we were sent to entertain the artillery corps, just three kilometers from the front. We drove through the mountains to a small village, where we were billeted in a charming white cottage. We set up in an old town hall, showing films, playing piano, and singing for two days. It was nerveracking trying to drown out the sound of artillery fire! ${ }^{22}$

\footnotetext{
${ }^{21}$ Charles K. Wolfe and James E. Akenson, Country Music Goes to War (Lexington: The University Press of Kentucky, 2005), 55.

${ }^{22}$ Mulvey, 'We Pulled Together... and Won!', 140.
} 


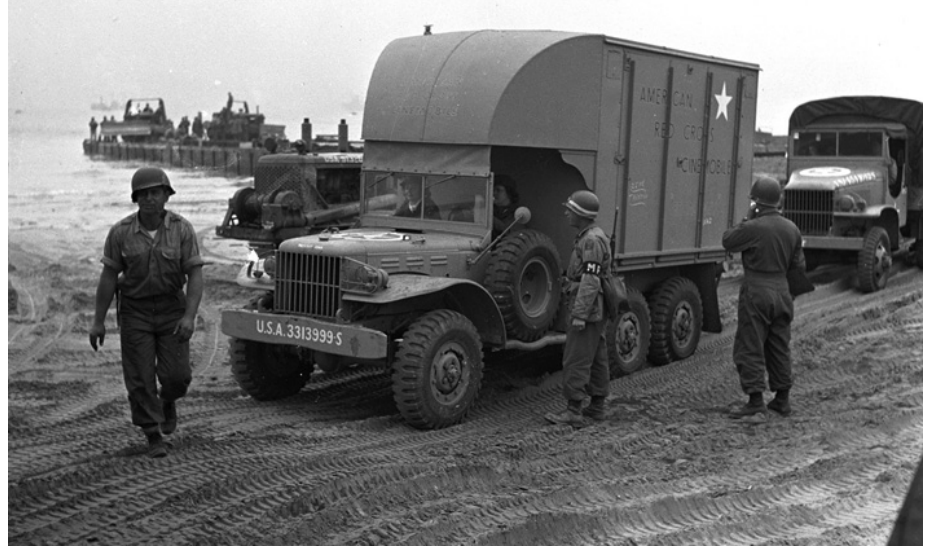

Figure 5: An American Red Cross Dodge WC-62 Cinemobile. ${ }^{23}$

Music served as a natural outlet through which the American people could express themselves during the war. The day that the Japanese surrendered was no exception. This day was known in history as Victory over Japan day, or V-J day. A girl by the name of Faye McDonald had just passed her sixth birthday at the war's end. Though still so tender in years, the events of that day remained etched in her memory for the rest of her life. She recalled a high school girl who climbed the city water tower with her trumpet and played "The Star-Spangled Banner." The residents of the town paused their work to listen. Some of them sang along, many of them cried, and all of them thanked God for the end of the war. The girl on the water tower went on to play "America the Beautiful" and other patriotic favorites. The townspeople crowded in a circle around the base of the tower and spent those golden minutes united in celebration. ${ }^{24}$ That little town of Lamar, Missouri joined its voice to the mass chorus of Americans singing praises of thanksgiving for the end of the war. The entire nation, joined together in combat, experienced the jubilant finale of their unity as they celebrated the success of their worldwide fight. Many of the same patriotic songs that had comforted them at the war's beginning now became the anthem of their joy at its end.

23 “WWII Red Cross Workers,” Histomil.com, accessed Jan. 23, 2018, http://histomil.com/viewtopic.php?t=17424.

${ }^{24}$ Mulvey, 'We Pulled Together... and Won!', 157. 
Thus, music played a significant part in boosting American patriotism and troop support during the crisis of World War II. Music provided a tangibility and expression to the emotional turmoil of American citizens in the war, who clung to songs commemorating parted lovers, marching soldiers, and patriotic citizens. These tunes became anthems and mottos of their daily existence. The songs lifted weary spirits and gave them strength to move on. Through music, America was solidified in unity, strength, stamina, and determination, and the country was given a voice that was heard and feared around the world.

\section{Bibliography}

Adamson, Harold, and Jimmy McHugh. "Comin' In on a Wing and a Prayer.” The Four Vagabonds. Bluebird Records 30-0815-A, 1943. "WWII in American Music," Authentic History Center, History on the Net. Accessed Apr. 06, 2017.

http://www.historyonthenet.com/authentichistory/1939-1945/3music/06-Services/19430000c_Comin_In_On_A_Wing And_A_Prayer-The_Four_Vagabonds.html.

Arsenault, Brian. "Brian Arsenault Takes On: Glenn Miller and His Orchestra.” The International Review of Music. Accessed Apr. 06, 2017. http://irom.wordpress.com/2014/10/02/brianarsenault-takes-on-the-glenn-miller-band/.

Beegle, Amy. “American Music Education 1941-1946: Meeting Needs and Making Adjustments during World War II.” Journal of Historical Research in Music Education 26, no. 1 (2004): 5467. doi:10.1177/153660060402600107.

"Biography.” Official Website of the Andrews Sisters. CMG

Worldwide. Accessed Apr. 06, 2017. http://www.cmgww.com/ music/andrews/.

"Biography.” Official Website of Glenn Miller. CMG Worldwide.

Accessed Jan. 23, 2018. http://www.glennmiller.com/ biography/.

Budanovic, Nikola. "Praise the Lord and Pass the Ammunition: The Legendary Army Chaplain of Pearl Harbor.” War History Online. http://www.warhistoryonline.com/world-war-ii/praisethe-lord-and-pass-the-ammunition-bc.html.

Crawford, Richard. America's Musical Life: A History. New York:

W.W. Norton \& Company, 2001. 
Committee on American Unity through Music. "American Unity through Music,” Music Educators Journal 27, no. 5 (1941): 10-13. doi:10.2307/3385961.

Evans, Redd, and John Jacob Loeb. "Rosie the Riveter.” The Four Vagabonds. Bluebird Records 30-0810-A, 1943. "WWII in American Music," Authentic History Center, History on the Net. Accessed Mar. 16, 2017. http://www.historyonthenet.com/ authentichistory/1939-1945/3-music/10-Pitching_In/ 19430200_Rosie_the_Riveter-The_Four_Vagabonds.html.

Friend, Cliff, and Charlie Tobias. "We Did It Before (And We Can Do It Again)." Barry Wood and the Wood-Nymphs. Victor Records 27783-A, 1941. "WWII in American Music," Authentic History Center, History on the Net. Accessed Mar. 16, 2017. http://www.historyonthenet.com/ authentichistory/1939-1945/3-music/04-PH-Reaction/ 19411200_We_Did_It_Before-Barry_Wood.html.

Garcia, Rachel. "World War II Homefront.” OAH Magazine of History 16, no. 3 (2002): 57-58. doi:10.1093/maghis/16.3.57.

Goble, J. Scott. "Nationalism in United States Music Education during World War II." Journal of Historical Research in Music Education 30, no. 2 (2009): 103-117. doi:10.1177/153660060903000203.

Loesser, Frank. "Praise the Lord and Pass the Ammunition.” Kay Kyser and His Orchestra. Columbia Records 36640, 1942. "WWII in American Music," Authentic History Center, History on the Net. Accessed Feb. 11, 2018. http://www.historyonthenet.com/ authentichistory/1939-1945/3-music/09-Names-Places/ 19420731_Praise_The_Lord_and_Pass_The_AmmunitionKay_Kyser.html.

Mulvey, Deb, ed. 'We Pulled Together...and Won!' Greendale, WI: Reminisce Books, 1993.

Parker, Nancy. "MEJ and World War II: A Review of Music Educators Journal, 1940-42.” Music Educators Journal 95, no. 2 (2008): 69-74. doi:10.1177/0027432108326472.

“Quotes.” Official Website of the Andrews Sisters. CMG Worldwide. Accessed Dec. 13, 2017. http://www.cmgww.com/ music/andrews/about/quotes/. 
Raye, Don, and Hughie Prince. "Boogie Woogie Bugle Boy.” Andrews Sisters with Vic Schoen and His Orchestra. Decca Records 3598-A, 1941. "WWII in American Music,” Authentic History Center, History on the Net. Accessed Feb. 11, 2018. http://www.historyonthenet.com/authentichistory/1939-1945/3music/03-Defense/19410112_Boogie_Woogie_Bugle_BoyAndrews_Sisters.html.

Roosevelt, Franklin D. “Day of Infamy” Speech. Dec. 8, 1941.

National Archives Catalog 595426. http://catalog.archives.gov/ id/595426.

Rose, Elihu. "The Forties and the Music of World War II.” History Now 32 (2012). The Gilder Lehrman Institute of American History. http://oa.gilderlehrman.org/history-by-era/world-warii/essays/forties-and-music-world-war-ii.

Van Der Vat, Dan. Pearl Harbor: The Day of Infamy-An Illustrated

History. Ontario, Canada: Madison Press Books, 2001.

Wolfe, Charles K. and James E. Akenson, eds. Country Music Goes to War. Lexington: The University Press of Kentucky, 2005.

"World War II Songs from the Belfer Audio Archive." Digital

Collection, Syracuse University Libraries.

http://ibrary.syr.edu/scrc/collections/digitalasset/belfer78.php.

"WWII in American Music." Authentic History Center, History on the Net. Last modified Nov. 21, 2014.

http://www.historyonthenet.com/authentichistory/1939-1945/3music/index.html.

Young, William H., and Nancy K. Young. American History through Music: Music of the World War II Era. Westport, CT:

Greenwood Press, 2008. 